\title{
SELECTION FOR ANTICOAGULANT THERAPY IN CARDIAC INFARCTION USING THE HEPARIN RETARDED COAGULATION TIME
}

\author{
BY \\ A. A. FITZGERALD PEEL \\ From the Victoria Infirmary at Glasgow
}

Received September 7, 1955

In an earlier publication (Peel, 1953) it was suggested that a modified form of Rosenthal's (1949) " Heparin-retarded coagulation time" (HRCT) could be used as a basis for determining the need for anticoagulant treatment in cardiac infarction. Preliminary findings showed a higher mortality and more frequent thrombo-embolic complications in patients with a short HRCT, although anticoagulants were given to them and withheld from those with a normal or prolonged HRCT. The present paper gives the results of four years' experience in the use of this method of selection.

\section{MATERIAL}

Although testing and selection have been carried out on patients seen at any time during the acute stage of coronary thrombosis only patients seen within seven days of the onset are considered in discussing the immediate prognosis and mortality (up to the end of the sixth week). The first week is by far the most dangerous period after a cardiac infarct. In a series of patients seen prior to 1950 (Peel, 1955), there were 45 deaths up to the end of the sixth week; of these, 17 occurred within four days, and 22 within seven days of the onset. Table I shows how the mortality figure in that series is affected by inclusion of patients who were not seen in the initial days of the attack. The highest mortality figure is obtained when patients seen within 48 hours of the onset are considered by themselves. The figure is only slightly reduced by inclusion of patients seen up to the end of the first week; but when those coming under observation for the first time in the second, third or fourth week are included, the apparent mortality is progressively lowered. In order to

TABLE I

Mortality of Cardiac Infarction as Affected by Inclusion in the Series of Patients SeEn for the First Time in the Later Stages of an AtTaCk. 1930/50 Series; Not HRCT Tested; No ANTICOAGUlants USED

\begin{tabular}{|c|c|c|c|c|c|}
\hline \multicolumn{3}{|c|}{ First seen } & $\begin{array}{l}\text { Number traced } \\
\text { to end of } \\
\text { sixth week }\end{array}$ & Deaths & $\underset{(\%)}{\text { Mortality }}$ \\
\hline $\begin{array}{l}\text { Within } \\
\text {," } \\
, \\
, \\
, \\
,\end{array}$ & 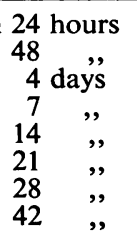 & $\begin{array}{l}. \\
. \\
\cdots \\
\cdots \\
\cdots \\
. \\
.\end{array}$ & $\begin{array}{r}57 \\
91 \\
132 \\
144 \\
174 \\
187 \\
198 \\
209\end{array}$ & $\begin{array}{l}15 \\
25 \\
33 \\
36 \\
41 \\
42 \\
43 \\
45\end{array}$ & $\begin{array}{l}26 \cdot 3 \\
27 \cdot 5 \\
24 \cdot 8 \\
25 \cdot 0 \\
23 \cdot 5 \\
22.4 \\
21 \cdot 7 \\
21 \cdot 5\end{array}$ \\
\hline
\end{tabular}


make it strictly comparable with the present series, the 1930/50 series has been re-analysed after excluding all patients who were first seen on the eighth day or later; details are given in Table II.

TABLE II

CARDIAC INFARCTION

Patients seen within seven days of onset. Mortality up to end of sixth week

\begin{tabular}{|c|c|c|c|c|c|c|c|}
\hline \multirow[t]{2}{*}{ History } & \multirow{2}{*}{$\begin{array}{l}\text { Sex, age, } \\
\text { shock } \\
\text { failure }\end{array}$} & \multicolumn{3}{|c|}{$\begin{array}{c}1930 / 50 \\
\text { No anticoagulants } \\
\text { (not HRCT tested) }\end{array}$} & \multicolumn{3}{|c|}{$\begin{array}{c}1951 / 54 \\
\text { Selection for anticoagulants } \\
\text { based on HRCT test }\end{array}$} \\
\hline & & Traced & Died & Per cent & Traced & Died & Per cent \\
\hline \multirow{6}{*}{$\begin{array}{l}\text { First attack } \\
\text { No previous cardiovas- } \\
\text { cular symptoms }\end{array}$} & $\begin{array}{l}\text { MALES } \\
28-49 \\
50-64 \\
65-85 \\
\text { Unknown }\end{array}$ & $\begin{array}{r}8 \\
33 \\
8\end{array}$ & $\begin{array}{l}0 \\
6 \\
3\end{array}$ & $\begin{array}{l}\text { Nil } \\
18 \cdot 2 \\
37 \cdot 6\end{array}$ & $\begin{array}{r}10 \\
17 \\
17 \\
2\end{array}$ & $\begin{array}{l}0 \\
2 \\
2 \\
0\end{array}$ & $\begin{array}{l}\text { Nil } \\
11 \cdot 7 \\
11 \cdot 7\end{array}$ \\
\hline & Total & 49 & 9 & $18 \cdot 3$ & 46 & 4 & 8.7 \\
\hline & $\begin{array}{c}\text { FEMALES } \\
40-64 \\
65-85\end{array}$ & $\begin{array}{l}2 \\
2\end{array}$ & $\begin{array}{l}1 \\
1\end{array}$ & & $\begin{array}{l}6 \\
4\end{array}$ & $\begin{array}{l}0 \\
1\end{array}$ & \\
\hline & Total & 4 & 2 & & 10 & 1 & \\
\hline & $\begin{array}{c}\text { SHOCK } \\
+ \\
-\end{array}$ & $\begin{array}{l}28 \\
25\end{array}$ & $\begin{array}{r}10 \\
1\end{array}$ & $\begin{array}{r}35 \cdot 8 \\
4 \cdot 0\end{array}$ & $\begin{array}{l}18 \\
38\end{array}$ & $\begin{array}{l}4 \\
1\end{array}$ & $\begin{array}{r}22 \cdot 2 \\
2 \cdot 6\end{array}$ \\
\hline & $\begin{array}{l}\text { CARDIAC } \\
\text { failure }\end{array}$ & 19 & 8 & $42 \cdot 1$ & 21 & 3 & $14 \cdot 4$ \\
\hline \multirow{6}{*}{$\begin{array}{l}\text { Previous coronary throm- } \\
\text { bosis, angina, exertion- } \\
\text { al dyspnœea, hyperten- } \\
\text { sion, peripheral or cere- } \\
\text { bral vascular disease }\end{array}$} & $\begin{array}{c}\text { MaLeS } \\
28-49 \\
50-64 \\
65-85 \\
\text { Unknown }\end{array}$ & $\begin{array}{l}10 \\
36 \\
15\end{array}$ & $\begin{array}{l}1 \\
4 \\
5\end{array}$ & $\begin{array}{l}10 \cdot 0 \\
11 \cdot 1 \\
33 \cdot 3\end{array}$ & $\begin{array}{r}10 \\
41 \\
19 \\
2\end{array}$ & $\begin{array}{r}1 \\
10 \\
10 \\
0\end{array}$ & $\begin{array}{l}10 \cdot 0 \\
24 \cdot 4 \\
52 \cdot 8\end{array}$ \\
\hline & Total & 61 & 10 & $16 \cdot 4$ & 72 & 21 & $29 \cdot 2$ \\
\hline & $\begin{array}{c}\text { FEMALES } \\
40-64 \\
65-85\end{array}$ & $\begin{array}{l}9 \\
8\end{array}$ & $\begin{array}{l}3 \\
1\end{array}$ & & $\begin{array}{r}8 \\
13\end{array}$ & $\begin{array}{l}1 \\
7\end{array}$ & \\
\hline & Total & 17 & 4 & $27 \cdot 8$ & 21 & 8 & $38 \cdot 1$ \\
\hline & $\begin{array}{c}\text { SHOCK } \\
\quad+ \\
-\end{array}$ & $\begin{array}{l}44 \\
34 \\
\end{array}$ & $\begin{array}{r}13 \\
1\end{array}$ & $\begin{array}{r}29 \cdot 6 \\
3.0\end{array}$ & $\begin{array}{l}38 \\
55\end{array}$ & $\begin{array}{l}19 \\
10\end{array}$ & $\begin{array}{l}50 \cdot 0 \\
18 \cdot 2\end{array}$ \\
\hline & $\begin{array}{r}\text { CARDIAC } \\
\text { FAILURE } \\
\end{array}$ & 21 & 5 & $23 \cdot 8$ & 34 & 14 & $41 \cdot 2$ \\
\hline \multicolumn{2}{|c|}{$\begin{array}{l}\text { CASES EXCLUDED } \\
\text { Died during examination } \\
\text { Moribund when seen } \\
\text { Unsuitable for HRCT as heparin al- } \\
\text { ready given .. } \\
\text { Short HRCT but refused treatment } \\
\text { No facilities for test .. } \ldots\end{array}$} & 9 & 9 & & $\begin{array}{r}3 \\
7 \\
15 \\
15 \\
3 \\
5\end{array}$ & $\begin{array}{l}3 \\
7 \\
4 \\
1 \\
0\end{array}$ & \\
\hline Total &. & 140 & 34 & $24 \cdot 2$ & 182 & 49 & $26 \cdot 9$ \\
\hline
\end{tabular}


Patients who were considered moribund when seen have been excluded both from the present series and from the revised 1930/50 figures. There were 9 such cases in 1930/50, and 10 in 1951/54; three of the latter actually died while being clinically examined. These 19 cases consisted of two men aged under 50, six aged 50-64, and seven aged 65 or over; with one women under 50 and three over 65 .

In practice it proved impracticable to test 23 patients and to order treatment accordingly. Thus three patients with an accelerated HRCT refused anticoagulant treatment; fifteen were unsuitable for testing as they had already been given heparin by their own doctor, and in the circumstances the treatment was simply continued without the selective test; finally, five patients were seen unexpectedly when tubes for the test were not available and these received no anticoagulants. Details of these excluded cases are given in Table II. There remain 149 patients in whom the test was used as the criterion for giving or withholding anticoagulants.

The technique of the test has already been described (Peel, 1953). Early in 1954 a minor modification was introduced when the apparent commencement of clotting was recorded as well as the end point, the result being expressed as " $15-18$ " or " $32-40$," etc. In most cases the decision for or against anticoagulant treatment was unaffected by this modification. In 11 instances, however, clotting commenced in less than 20 minutes, but was still incomplete in 20 minutes. These cases would not have received anticoagulants prior to 1954; nevertheless, ten were given anticoagulants and have been included in the "short HRCT" group. The eleventh patient received no anticoagulants and is included in the " normal HRCT" group; he died suddenly and unexpectedly during the third week.

The anticoagulant used during the first two years of this study was ethyl biscoumacetate (tromexan), and during the last two years phenylindanedione (dindevan). In either case heparin has been used at the start of treatment until satisfactory prolongation of the prothrombin time has been obtained, and also later in treatment whenever the prothrombin time has dropped temporarily below the desired level. A prothrombin level of two-and-a-half times the control figure has been the aim; heparin has been given when the level has been less than twice the control value. No hæmorrhagic complications have been encountered. We have noted no difference in the ultimate results with dindevan as compared with tromexan, but we are convinced that dindevan is more easily controlled, produces a more constant prolongation of prothrombin time, and requires fewer changes in dosage. Anticoagulants were given for three weeks initially; subsequent treatment was based on the HRCT.

\section{RESULTS AND DisCUSSION}

The importance of age and sex in any consideration of the mortality of cardiac infarction has already been stressed (Peel, 1955). A further factor that has turned out to be of supreme importance in relation to the present investigation is the patient's previous history. The difference between patients with and those without a history of previous cardiovascular disease is so great that it is necessary to discuss them separately; and they have been kept separate in all relevant tables. Prodromal symptoms preceding an attack for a few days or weeks have not been regarded as constituting " previous cardiovascular disease"; this has been accepted as present when there has been a history of angina of effort or exertional dyspnœa at a constant level over a period of months or years, a previous coronary thrombosis, a cerebral vascular accident, peripheral vascular disease, or pre-existing hypertension.

First Attacks without Preceding Cardiovascular Disease. It is clear that in this group the method of selection has met with considerable success. The mortality was halved as compared with 1930/50 (Table II). The improvement is seen in both sexes and at all ages; it is particularly striking in the older age group which normally carries a much higher risk. Table III shows that the test is capable of selecting a group of patients who do not require anticoagulants; there was not a single death among the 28 patients whose HRCT remained normal; of the five deaths, four occurred in 
TABLE III

CARDIAC INFARCTION

$1951 / 54$ series analysed

\begin{tabular}{|c|c|c|c|c|c|c|c|c|c|}
\hline \multirow{3}{*}{ History } & \multirow{3}{*}{$\begin{array}{c}\text { Sex, age, } \\
\text { shock } \\
\text { failure }\end{array}$} & \multicolumn{3}{|c|}{$\begin{array}{c}\text { HRCT under } 20 \\
\text { (anticoagulants given) }\end{array}$} & \multicolumn{3}{|c|}{$\begin{array}{c}\text { HRCT over } 20 \\
\text { (anticoagulants withheld) }\end{array}$} & \multirow{2}{*}{\multicolumn{2}{|c|}{$\begin{array}{l}\text { HRCT normal } \\
\text { at first, later } \\
\text { accelerated; } A / C \\
\text { started then }\end{array}$}} \\
\hline & & \multirow{2}{*}{ No. } & \multirow{2}{*}{ Died } & \multirow{2}{*}{ Per cent } & \multirow{2}{*}{ No. } & \multirow{2}{*}{ Died } & \multirow{2}{*}{ Per cent } & & \\
\hline & & & & & & & & No. & Died \\
\hline \multirow{6}{*}{$\begin{array}{l}\text { First attack } \\
\text { No previous cardio- } \\
\text { vascular symptoms }\end{array}$} & $\begin{array}{l}\text { MALES } \\
28-49 \\
50-64 \\
65-85 \\
\text { Unknown }\end{array}$ & $\begin{array}{l}3 \\
8 \\
8 \\
0\end{array}$ & $\begin{array}{l}0 \\
2 \\
1 \\
0\end{array}$ & & $\begin{array}{l}6 \\
9 \\
8 \\
1\end{array}$ & $\begin{array}{l}0 \\
0 \\
0 \\
0\end{array}$ & & $\begin{array}{l}1 \\
0 \\
1 \\
1\end{array}$ & $\begin{array}{l}0 \\
0 \\
1 \\
0\end{array}$ \\
\hline & Total & 19 & 3 & $15 \cdot 8$ & 24 & 0 & Nil & 3 & 1 \\
\hline & $\begin{array}{c}\text { FEMALES } \\
40-64 \\
65-85\end{array}$ & $\begin{array}{l}2 \\
3\end{array}$ & $\begin{array}{l}0 \\
1\end{array}$ & & $\begin{array}{l}3 \\
1\end{array}$ & $\begin{array}{l}0 \\
0\end{array}$ & & $\begin{array}{l}1 \\
0\end{array}$ & $\begin{array}{l}0 \\
0\end{array}$ \\
\hline & Total & 5 & 1 & $20 \cdot 0$ & 4 & 0 & Nil & 1 & 0 \\
\hline & $\begin{array}{c}\text { SHOCK } \\
+ \\
-\end{array}$ & $\begin{array}{r}15 \\
9\end{array}$ & $\begin{array}{l}4 \\
0\end{array}$ & $26 \cdot 6$ & $\begin{array}{r}2 \\
26\end{array}$ & $\begin{array}{l}0 \\
0\end{array}$ & & $\begin{array}{l}1 \\
3\end{array}$ & $\begin{array}{l}0 \\
1\end{array}$ \\
\hline & $\begin{array}{l}\text { CARDIAC } \\
\text { FAILURE }\end{array}$ & 11 & 3 & & 10 & 0 & & 0 & 0 \\
\hline \multirow{6}{*}{$\begin{array}{l}\text { Previous coronary } \\
\text { thrombosis, angina, } \\
\text { exertional dyspnoea } \\
\text { hypertension, peri- } \\
\text { pheral or cerebral } \\
\text { vascular disease }\end{array}$} & $\begin{array}{l}\text { MALES } \\
28-49 \\
50-64 \\
65-85 \\
\text { Unknown }\end{array}$ & $\begin{array}{r}9 \\
20 \\
9 \\
2\end{array}$ & $\begin{array}{l}1 \\
4 \\
5 \\
0\end{array}$ & $\begin{array}{l}11 \cdot 1 \\
20 \cdot 0 \\
55 \cdot 6\end{array}$ & $\begin{array}{r}1 \\
14 \\
8 \\
0\end{array}$ & $\begin{array}{l}0 \\
3 \\
4 \\
0\end{array}$ & $\begin{array}{l}21 \cdot 4 \\
50 \cdot 0\end{array}$ & $\begin{array}{l}0 \\
7 \\
2 \\
0\end{array}$ & $\begin{array}{l}0 \\
3 \\
1 \\
0\end{array}$ \\
\hline & Total & 40 & 10 & $25 \cdot 0$ & 23 & 7 & $30 \cdot 4$ & 9 & 4 \\
\hline & $\begin{array}{c}\text { FEMALES } \\
40-64 \\
65-85\end{array}$ & $\begin{array}{r}8 \\
10\end{array}$ & $\begin{array}{l}1 \\
6\end{array}$ & & $\begin{array}{l}0 \\
2\end{array}$ & $\begin{array}{l}0 \\
0\end{array}$ & & $\begin{array}{l}0 \\
1\end{array}$ & $\begin{array}{l}0 \\
1\end{array}$ \\
\hline & Total & 18 & 7 & $38 \cdot 8$ & 2 & 0 & & 1 & 1 \\
\hline & $\begin{array}{c}\text { SHOCK } \\
+ \\
-\end{array}$ & $\begin{array}{l}23 \\
35\end{array}$ & $\begin{array}{r}10 \\
7\end{array}$ & $\begin{array}{l}43 \cdot 5 \\
20 \cdot 0\end{array}$ & $\begin{array}{l}10 \\
15\end{array}$ & $\begin{array}{l}5 \\
2\end{array}$ & $\begin{array}{l}50 \cdot 0 \\
13 \cdot 3\end{array}$ & $\begin{array}{l}5 \\
5\end{array}$ & $\begin{array}{l}4 \\
1\end{array}$ \\
\hline & $\begin{array}{l}\text { CARDIAC } \\
\text { FAILURE }\end{array}$ & 20 & 8 & $40 \cdot 0$ & 9 & 2 & $22 \cdot 2$ & 5 & 4 \\
\hline
\end{tabular}

patients whose HRCT was short and who received anticoagulants from the start; three were sudden and unexpected while the fourth was due to rupture of the infarct. The fifth death was in a man of 66 whose HRCT was prolonged (60 minutes) on the first day; it became accelerated (17 minutes) on the fourth day and anticoagulants were then started; paroxysmal auricular fibrillation appeared on the seventh day, intermittent ventricular tachycardia on the twelfth day, while on the eighteenth day he had a lung infarct; he died suddenly on the twentieth day.

On the basis of the $1930 / 50$ figures, the deaths " expected" in 1951/54 total 15, made up as follows: men 50-64, four; 65-85, six; women 40-64, three, 65-85, two. As the 28 patients with a normal HRCT were treated exactly like the 1930/50 cases and yielded no deaths, the "expected" 
deaths must be assigned to the group of 28 patients whose HRCT was accelerated from the start or became accelerated later, an " expected" mortality of 53.6 per cent. The experienced mortality was 17.8 per cent in this group, and the difference is a measure of the benefit of anticoagulant treatment in those patients who genuinely require it. Although intravenous noradrenaline drip transfusions were used in some of the patients who had a history of previous cardiovascular disease, they were not needed or used in any of these patients without a preceding cardiovascular history, the administration or anticoagulants being the only respect in which treatment differed from that given to the $1930 / 50$ cases and the $1951 / 54$ " normal HRCT" cases.

Contrary to our earlier experience, there seems to be a definite relationship between the HRCT and the presence or absence of shock in these patients with first attacks. Shock was present in 15 of 24 patients in the " short HRCT" group, but in only 2 of 28 with a normal HRCT. On the other hand, failure was only a little less frequent in those with a normal HRCT (10 out of 28) than in those with acceleration (11 out of 24).

Follow-up figures to the end of the first year are still incomplete, but information available to date shows 7 recurrences and 2 instances of embolism among 24 " short HRCT, anticoagulanttreated" cases $(37.5 \%)$ as compared with 3 recurrences and no emboli among 27 " normal HRCT, no anticoagulant" cases $(11 \%)$. On the other hand, deaths were fewer in the anticoagulanttreated group $(4=17 \%$ as compared with $7=26 \%)$.

History of Preceding Cardiovascular Disease Present. In the presence of a history of preceding cardiovascular disease, the results both of HRCT testing and of anticoagulant treatment can only be described as depressing. In the 1930/50 series there was little difference between those with and those without previous cardiovascular disease (Table II); but a number of such patients were seen rather late in their illness, and the figures quoted in our earlier publication (which include patients seen after the eighth day) show a slightly higher mortality in those with preceding cardiovascular symptoms. On the other hand, in $1951 / 54$ the mortality was very much higher $(31 \%$ as compared with $18 \%$ ) and it was three times the mortality of those with no previous cardiovascular disease. The increased mortality was distributed more or less uniformly among all groups, irrespective of the HRCT and of the giving or withholding of anticoagulants. The death rate in the anticoagulant-treated cases was 32 per cent and in the "normal HRCT" group who received no anticoagulants it was 28 per cent. The high mortality cannot, therefore, be attributed to the withholding of anticoagulants, but would seem to be related to the extent of pre-existing cardiac damage. Furthermore, the figures suggest that, while anticoagulants may conceivably be of prophylactic value in warding off an attack in such patients, they are of no therapeutic value once the attack has occurred.

The relationship between the HRCT and shock no longer holds good in patients with previously damaged hearts. Shock was present in 23 out of 55 with a short HRCT and in 10 out of 25 with a normal HRCT. Failure was present in 18 of 55 with a short HRCT and in 9 of 25 with a normal HRCT. On the other hand the test still gave a reasonable index of the danger of extension of the infarct or of embolism. There were five deaths from extension and two from embolism among the 58 patients with a short HRCT (despite anticoagulant treatment); one death from extension and one from embolism among 10 patients whose HRCT became accelerated later; but only one death from extension and none from embolism among the 25 patients whose HRCT remained normal. The high mortality in this latter group is made up with three deaths from failure $(12 \%)$ and three sudden deaths $(12 \%)$.

The later follow-up in these patients presents a much less gloomy picture. The mortality to the end of the first year was almost identical with that in 1930/50, and little different from that of patients with no preceding cardiovascular disease (Table IV). Once again, recurrences and emboli were more frequent in those who had received anticoagulant treatment because of a short HRCT (six instances among 32 patients, 18.7\%) than in those whose HRCT was normal and who received no anticoagulant (one instance among 23 patients, $4 \cdot 4 \%$ ). 
TABLE IV

CARDIAC INFARCTION

Follow-up of Survivors to end of first year

\begin{tabular}{|c|c|c|c|c|c|}
\hline & & \multirow[b]{2}{*}{$1930 / 50$} & \multirow{2}{*}{$\begin{array}{l}1951 / 54 \\
\text { Total }\end{array}$} & \multicolumn{2}{|c|}{$1951 / 54$ series analysed } \\
\hline & & & & $\begin{array}{l}\text { Short HRCT* } \\
(\mathrm{A} / \mathrm{C}+)\end{array}$ & $\begin{array}{c}\text { Normal HRCT } \\
(\text { No } A / C)\end{array}$ \\
\hline 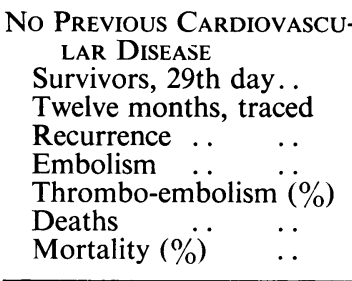 & $\begin{array}{l}- \\
\cdots \\
\cdots \\
\cdots \\
\cdots \\
\cdots \\
\cdots\end{array}$ & $\begin{array}{r}129 \\
89 \\
7 \\
2 \\
10 \cdot 1 \\
12 \\
13 \cdot 5\end{array}$ & $\begin{array}{c}118 \\
51 \\
10 \\
2 \\
23 \cdot 6 \\
11 \\
21 \cdot 6\end{array}$ & $\begin{array}{c}38 \\
24 \\
7 \\
2 \\
37 \cdot 5 \\
4 \\
16 \cdot 7\end{array}$ & $\begin{array}{r}77 \\
27 \\
3 \\
0 \\
11 \cdot 1 \\
7 \\
25 \cdot 9\end{array}$ \\
\hline $\begin{array}{l}\text { PREVIOUS CARDIOVASCULAR } \\
\text { DISEASE } \\
\text { Survivors, 29th day.. } \\
\text { Twelve months, traced } \\
\text { Recurrence .. .. } \\
\text { Embolism . . } \\
\text { Thrombo-embolism (\%) } \\
\text { Deaths } . . . \\
\text { Mortality (per cent) }\end{array}$ & $\begin{array}{l} \\
\cdots \\
\cdots \\
\cdots \\
\cdots \\
\cdots \\
\cdots \\
\cdots\end{array}$ & $\begin{array}{r}128 \\
87 \\
8 \\
5 \\
14 \cdot 9 \\
20 \\
23 \cdot 0\end{array}$ & $\begin{array}{c}97 \\
55 \\
6 \\
1 \\
12 \cdot 7 \\
13 \\
23 \cdot 6\end{array}$ & $\begin{array}{r}75 \\
32 \\
5 \\
1 \\
18 \cdot 7 \\
8 \\
25 \cdot 0\end{array}$ & $\begin{array}{c}78 \\
23 \\
1 \\
0 \\
4 \cdot 4 \\
5 \\
21 \cdot 7\end{array}$ \\
\hline
\end{tabular}

* Seven patients whose HRCT was originally normal but became accelerated subsequently are included in the "Short HRCT" group in this table; among these there were two recurrences (non-fatal), two deaths, and no instances of embolism.

Note.-In addition to cases seen within seven days of onset, this table includes those first seen between the eighth and twenty-eighth days (151 in 1930/50, 100 in 1951/54).

Prophylactic Use of Anticoagulants in Cardiac Ischamia. Cases of cardiac ischæmia seen during 1951/54 have been HRCT tested and those with a short HRCT have been given a prophylactic course of anticoagulant treatment. The results are compared in Table $\mathrm{V}$ with those found in 1930/50 when no anticoagulants were used. The incidence of infarct in 1930/50 was 11 per cent within six weeks of onset. In 1951/54 the incidence was 7 per cent in patients with a normal HRCT and 8 per cent in those with a short HRCT who received prophylactic treatment.

TABLE V

Cardiac Ischemia; InCIDEnce of Infarction Within Six WeEks of ONSET

\begin{tabular}{|c|c|c|c|c|c|}
\hline & & $\begin{array}{l}\text { Total } \\
\text { seen }\end{array}$ & $\begin{array}{l}\text { Traced } \\
6 \text { weeks }\end{array}$ & $\begin{array}{l}\text { Developed } \\
\text { infarct }\end{array}$ & $\begin{array}{c}\text { Incidence } \\
(\%)\end{array}$ \\
\hline $1930 / 50$ & $\ldots$ & 167 & 150 & 17 & $11 \cdot 3$ \\
\hline $\begin{array}{c}1951 / 54 \underset{5}{\text { Short HRCT }}(\mathrm{A} / \mathrm{C} \\
\text { treated) }\end{array}$ & & 48 & 39 & 3 & $7 \cdot 7$ \\
\hline $\begin{array}{c}1951 / 54 \underset{\text { (untreated) }}{\text { Normal HRCT }} \\
. .\end{array}$ & $\ldots$ & 78 & 59 & 4 & 6.9 \\
\hline
\end{tabular}




\section{SUMMARY}

Rosenthal's " heparin-retarded coagulation time" test has been used in 149 cases of cardiac infarction, those with acceleration of clotting being treated with anticoagulants, while those with a normal or prolonged clotting time received no anticoagulants.

In patients who had no history of previous cardiovascular disease this procedure halved the mortality. Anticoagulants were unnecessary in those whose HRCT remained normal; there were 28 such patients with no deaths. In those with accelerated HRCT, anticoagulants reduced an " expected" mortality of 54 per cent to 18 per cent. Recurrence or embolism within one year was three times more frequent in those with a short HRCT than in those with a normal HRCT.

In patients with a history of previous cardiovascular disease the mortality remained high irrespective of the HRCT, and anticoagulants seemed incapable of reducing it. Nevertheless, death from extension of the infarct or from embolism was more frequent when the HRCT was accelerated, in spite of anticoagulant treatment.

The test was also used in 126 cases of cardiac ischæmia to determine the need for prophylactic anticoagulant treatment; the incidence of infarction within six weeks of the onset of ischæmia was reduced from 11 per cent in an earlier series, to 7 per cent in this series.

I would again acknowledge with thanks the invaluable help of numerous general practitioners who have given information regarding the subsequent course of their patients; of my secretaries Miss A. E. Watson and Mrs. E. Yarr; of the staff of the Pathology Department and of the residents at the Victoria Infirmary.

\section{REFERENCES}

Rosenthal, R. L. (1949). J. Lab. Clin. Med., 34, 1321.

Peel, A. A. F. (1953). Brit. Heart J., 15, 8.

- (1955). Brit. Heart J., 17, 319. 